\title{
BASE SINGLE PART PRODUCT QUALITY CONTROL USING STATISTICAL QUALITY CONTROL (SQC) METHOD IN PT DIRGANTARA INDONESIA MACHINING DEPARTMENT
}

\author{
Doni Riadi ${ }^{1}$, Ade Geovania Azwar ${ }^{2}$ \\ ${ }_{1,2}$ Prodi Teknik Industri, Fakultas Teknik, Universitas Sangga Buana \\ ${ }^{1}$ korespondensi : riadidoni8@gmail.com
}

\begin{abstract}
Base Single Part is the main component of the cable installation that functions as a connector between cables in the aircraft. As a critical part, the Base Single Part is the most important sub-component that must be completed to be installed in the aircraft part. Base Single Part is a part that is used in all types of aircraft which are specially produced at PT. Dirgantara Indonesia, in one aircraft this component can be installed in the amount of 8000-9000 Base Single Part. In relation to the request from the Final Assembly Line section regarding the request for the Base Single Part component, there are still some products that do not meet the specifications so that they have to be repaired, such as holes that do not match the size, this causes the delivery order process to the Final Assembly Line section to be hampered and disruptive smooth production. The purpose of this research is to control the quality of the Base Single Part product by using a p control chart, and a causal diagram. The results of the study conclude that the calculation of the percentage level of defect in the Base Single Part component using the $\mathrm{p}$ control chart, there are 3 percentage points that are outside the control limit, namely in August with a disability percentage of $15.11 \%$, in September $10.32 \%$, and October $15.60 \%$. Factors causing defects in Base Single Part components consist of 3 factors, human factors, method factors and machine factors. The human factor is workers who are less productive. Furthermore, the method factor is regarding the fluctuating production schedule and the last cause is the machine factor that lacks maintenance.
\end{abstract}

Keywords : Control Diagram p, Cause and Effect Diagram (Fishbone), Base Single Part

\section{INTRODUCTION}

The Machining Department of PT Dirgantara Indonesia which makes Base Single Part components strives to make continuous product and quality improvements by minimizing products that do not meet specifications. Base Single Part is the main component of cable installation that functions as a connector between cables in the aircraft, this sub component has the most process sequences and has more difficulty levels than other components such as Tube Single Part, Skin De Nose, Door Assy and others. As a critical part, then Base Single Part is the most important sub-component that must be completed to be installed in the aircraft part, because these sub-components are very numerous and important for connecting the installation of electricity between components on the plane, besides this Base Single Part is a part that is used in all types of aircraft specifically in Indonesia. production of PT. Dirgantara Indonesia, in one aircraft this component can be installed in the amount of 8000-9000 Base Single Part. In connection with the request from the FAL (Finel Assembly Line) section regarding the request for this Base Single Part component, the Machining Department always tries to fulfill the request even though in reality there are always some products that do not meet the expected specifications so that they have to be repaired or reworked, such as holes that are damaged. not according to size, the 
following is data regarding the number of defective or do not meet specifications: components of the Base Single Part that are

Table 1 : Production Quantity Data Base Single Part

\begin{tabular}{|c|l|c|c|}
\hline No & Period & $\begin{array}{c}\text { Production } \\
\text { Quantity } \\
(\text { Pcs })\end{array}$ & $\begin{array}{c}\text { Number of } \\
\text { Defects (Pcs) }\end{array}$ \\
\hline 1 & Januari & 845 & 119 \\
\hline 2 & Februari & 368 & 52 \\
\hline 3 & Maret & 739 & 105 \\
\hline 4 & April & 964 & 134 \\
\hline 5 & Mei & 1267 & 173 \\
\hline 6 & Juni & 2415 & 294 \\
\hline 7 & Juli & 3329 & 396 \\
\hline 8 & Agustus & 2178 & 329 \\
\hline 9 & September & 2819 & 291 \\
\hline 10 & Oktober & 3642 & 568 \\
\hline 11 & Nopember & 3449 & 394 \\
\hline 12 & Desember & 3207 & 347 \\
\hline & Total & $\mathbf{2 5 2 2 2}$ & $\mathbf{3 2 0 2}$ \\
\hline
\end{tabular}

The existence of defective products that are produced indicates that the existing quality control system still needs to be repaired, because this can cause rework activities to be carried out (repair), if the defective / reject product is not followed up, and the consequences of repeated work will disrupt smooth production and delivery orders are hampered, thus the product quality control program implemented by the company is not optimal so it is necessary to carry out quality control efforts implemented by the Machining Department of PT. Indonesian Aerospace.

The purpose of this study is to determine the percentage of disability level Base Single Part is it still within the control limits or can be tolerated and to find out what factors cause it the occurrence of defects in the production process Base Single Part.

\section{LITERATURE REVIEW}

\section{Definition of Quality}

Quality is confermance to requirement, which is in accordance with what is required or standardized, a product has quality if it is in accordance with predetermined quality standards, quality standards include raw materials, production processes and finished products [1]. The objectives of quality control are as follows [2]:

1. So that the goods produced can reach the quality standards that have been set.

2. Strive for inspection costs to be as small as possible. 
3. Strive for the design costs of products and processes using certain production qualities to be as small as possible.

4. Strive for production costs to be as low as possible.

\section{Statistical Quality Control (SQC)}

Statistics is a decision-making tool about a process or analysis of information contained in a sample. In quality assurance, statistical methods play an important role, in operational management, quality control methods using / statistical methods are called Statistical Quality Control which is a system developed to maintain standards of product quality, at low cost levels minimum by using the method statistics to collect and analyze data. The main purpose of statistical control is to detect the existence of special causes in variations or process errors through data analysis from the past and the future, in other words looking for the cause of damage or product defects through existing data, so that repairs can be done quickly so that the same error does not occur. reoccur. Decision making in Statistical Quality Control can use a tool known as the seven tools [4]. The step in reducing the level of defects is to carry out quality control in the production process to find out the factors that cause the greatest level of defects and determine whether the process is under control or not, this can be done by making improvements and improving product quality during the production process. [3].

SPC (Statistical Process Control) is a method that is related to the SQC method. SPC is a statistical method that separates causal and scientifically generated variations to eliminate (SPC) is a process used to monitor standards, make measurements and take corrective action during a product or service being produced [2]. process control statistical (Statistical Process Control - SPC) used to describe a sampling-based model that is applied to observe interrelated process activities.

SPC is a very useful tool in ascertaining whether a process remains within the defined limits, but generally it cannot provide a way to keep the process within control limits. Statistical process control emphasizes more on controlling and process improvement based on data analyzed using statistical tools [5]. Statistical Process Control (SPC), are two interchangeable terms, which when carried out simultaneously, the user will see a picture of current and future process performance. This is because Statistical Process Control (SPC) is known as an online tool to describe what is happening in the current process [6]. Here's a summary of the differences between SQC and SPC. 
Table2 : Difference SQC dan SPC

\begin{tabular}{|c|c|}
\hline Statistical Quality Control (SQC) & Statistical Process Control (SPC) \\
\hline $\begin{array}{c}\text { SQC refers to the use of statistical tools to analyze } \\
\text { variations in a manufacturing process to make it } \\
\text { better. }\end{array}$ & $\begin{array}{c}\text { SPC is a category of SQC that also uses statistical } \\
\text { tools to monitor and control the production process } \\
\text { to ensure the production of uniform products with } \\
\text { less waste. }\end{array}$ \\
\hline $\begin{array}{c}\text { SQC uses a certain number of samples to determine } \\
\text { the acceptance of a product. }\end{array}$ & $\begin{array}{c}\text { SPC inspects the production process for flaws that } \\
\text { could lead to low-quality products. }\end{array}$ \\
\hline $\begin{array}{c}\text { SQC looks for the cause of damage or product defects } \\
\text { through existing data or it can be from past data. }\end{array}$ & $\begin{array}{c}\text { SPC looks for the cause of damage or product } \\
\text { defects through product data that is being produced. }\end{array}$ \\
\hline
\end{tabular}

\section{The Seven Quality Control Tools}

The Seven Quality Control Tools are useful tools for mapping the scope of the problem, organizing data in diagrams to make it more easy to understand, browse various possible causes of problems and clarify authentic facts or phenomena in a problem, the types of tools that are included in "The 7 QC Tools" are as follows [7]:

1. Diagram Alir (Flow Chart)

2. Diagram Kendali (Control Charts)

3. Lembar Periksa (Check Sheet)

4. Diagram Sebab Akibat (Cause \& Effect Diagrams)

5. Diagram Pareto (Pareto Diagrams)

6. Histogram

7. Diagram Pencar (Scatter Diagrams)

The key to success in solving any quality problem is identifying the problem followed by an analytical tool approach according to the characteristics of the problem then informing the solution to other units, in the production process, most people tend to use Pareto Diagrams and Cause \& Effect Diagrams control tools before using other quality testing tools. This causes these two tools to be more widely used in production quality control. Below is a more detailed description of the Seven Quality Control Tools (The Seven Tools). Below is an explanation of the seven controllers.

\section{Flow Chart}

Flow chart is a schematic depiction that shows all the steps in a process and shows how these steps interact with each other. Everyone who is responsible for improving some way to describe the flow chart with the various symbols used [1].

\section{Control Chart}

Control charts are used to measure averages, variables, and attributes. Variables relate to the average and the magnitude of the deviation as well as to determine the axis of the occurrence of process variations. Measurement of variables is useful in monitoring ongoing operations, while attribute measurement is related to the large percentage of rejected products and is important in acceptance sampling. The following is a control diagram method, namely [1]

a. Diagram kontrol $p$

P control chart (damage proportion control chart) is a statistical process control tool, $\mathrm{p}$ 
control chart is used to measure the proportion of non-conformances (deviations or often called defects) of items in the group being inspected. Thus the control chart $\mathrm{p}$ is used to control the proportion of items that do not meet the quality specification requirements or the proportion of defective products produced by a process, the unqualified proportion is defined as the ratio of the number of unqualified items in a group to the total number items in that group [8].

$\mathrm{BKA}$ and $\mathrm{BKB}$ lines can be determined by size or location by using the $\mathrm{p}$ control chart quality control technique to measure attributes, if the desired probability of the product is in control, then the magnitude of the central line $(p)$ is as follows [1]:

$\overline{\mathrm{p}}=$ Sentral $=\frac{\text { jumlah proposi rusak }}{\text { jumlah sampel yang diperiksa }}$

$\mathrm{BKA}_{\mathrm{p}}=\overline{\mathrm{p}}+3 \sqrt{\frac{\overline{\mathrm{p}} \cdot \overline{\mathrm{q}}}{\mathrm{n}}}$

$\mathrm{BKB}_{\mathrm{p}}=\overline{\mathrm{p}}-3 \sqrt{\frac{\overline{\mathrm{p} \cdot \mathrm{q}}}{\mathrm{n}}}$

Keterangan :

BKA = Upper Control Limit (UCL)

$\mathrm{BKB}=$ Lower Control Limit (LCL)

$\mathrm{p}=$ How many rejected from the checked amount

$\mathrm{n}=$ Number of items in each sample $\overline{\mathrm{q}}=1-\overline{\mathrm{p}}$

Data that is a defect from the output is plotted on a control chart, if there is no data that is out of the upper control limit (BKA) or lower control limit (BKB), and the data plot does not show any symptoms of deviation, it can be said that the process is under control, on the contrary. if there is data that is out of the control limits, then the process is not stable, the data that is out of the control limits is due to a special cause [9].

\section{Check Sheet}

According to [1] Check paper is the easiest tool to calculate how often something happens. Thus, the check sheet is a simple, but regular tool for data collection, recording data to find out the main problem, in compiling the check sheet it is important to note that everyone knows and agrees on what to count, how to calculate it, and when to calculate it. The preparation of the examination paper must pay attention to the following things:

1) The form of the columns for recording data must be clear.

2) The data to be collected and recorded must have a clear purpose.

3) When data should be collected and included.

\section{Fishbone Diagram}

Diagram sebab akibat (cause and effect diagram) or often referred to as "fishbone diagrams" (fishbone diagrams) or ishikawa diagrams (ishikawa diagram), according to the name of Prof. Kaora Ishikawa from Japan introduced this diagram. A cause-and-effect diagram is a structured approach that allows a more detailed analysis to be carried out in finding the causes of problems, discrepancies, and gaps that occur. This diagram can be used in situations where there is a discussion meeting using brainstorming 
to identify why a problem occurs, a more detailed analysis of a problem is needed, and it is difficult to separate causes from effects [1].

The steps in a cause-and-effect analysis are:

1. Define the problem. This step can use the results of data histograms, control charts, Pareto charts, and so on.

2. Selection of analytical methods. Often the method of analysis involves a joint contribution to a team representing the production, engineering, inspection, and other potentially involved departments of the problem being studied.

3. Draw the problem box and the main (center) arrow.

4. Specify the main categories of sources that might contribute to the problem.

5. Identify the possible causes of this problem.

6. Analyze the causes and take corrective action

\section{Pareto Chart}

A Pareto chart is an item graph that shows problems in order of number of occurrences. The most common problems are shown by the graph the first stem highest and placed on the left side, and so on until the problem with the fewest occurrences is shown by the last lowest bar graph and is placed on the far right side position [8].

According to [1] Pareto chart is a diagram developed by an Italian economist named Vilfredo Pareto in the 19th century. Pareto charts are used to compare various categories of events arranged according to size, from the largest on the left to the smallest on the right. . This arrangement will help us to determine the importance or priority of the categories of events or the causes of the events being studied or to find out the main problems of the process, with the help of the Pareto chart, activities will be more effective by focusing on the causes that have the most impact. greater attention to events than to review various causes at one time. The use of the Pareto chart is as follows:

a) Shows priority causes of events or problems that need to be addressed.

b) Pareto charts can help to focus attention on the main problems that must be addressed in the improvement effort.

c) Shows the results of improvement efforts. After taking corrective actions based on priority, we can carry out remeasurements and create a new Pareto chart. If there is a change in the new Pareto chart, then corrective action has effect.

d) Arrange data into useful information. With Pareto Charts, amount of data large ones can be significant information.

\section{Histogram}

Histogram is a tool to show variations in measurement data, such as the weight of a group of people, the thickness of the iron plate, and so on. Like the Pareto chart, the histogram is in the form of a bar graph that shows the frequency distribution. However, the histogram is different from the Pareto chart because the bar graph is not drawn 
descending from left to right. The histogram bar graph is arranged along the range of the measurement data. Furthermore, the Pareto chart also only shows the characteristics of goods or services, such as the type of disability, accident, damage and so on.

The histogram shows measurement data, such as weight, temperature, height, and so on. In this way, the histogram can be used to show the variation of each process. According to [8] histogram is one tool that helps us to find variations. The histogram is a snapshot of the process showing the distribution of the measurements, and the frequency of each measurement. Thus the histogram can be used as a tool to communicate information about variations in the process, and assist management in making decisions that focus on continuous improvement efforts. Frequency distribution and histograms summarize information about the value of quality characteristics and present it in a format that allows us to draw a conclusion regarding the information [10].

Histogram is a graphical display to show the distribution of data visually or how often a different value occurs in a data set. Histogram is also one of the 7 tools of quality control (QC 7 Tools). The benefits of using Histograms are to provide information about process variations and assist management in making decisions in an effort to continuously improve processes (continuous process improvement).

\section{Diagram Pencar (Scatter Diagram)}

This scatter diagram is a picture that shows the possible relationship (correlation) between a pair of two kinds of variables. Although there is a relationship, but it does not mean that one variable causes another variable to arise. Scatter diagrams usually explain the existence of a relationship between two variables and show the closeness of the relationship which is manifested as a correlation coefficient [1]. The two variables shown in the scatter diagram can be:

1. Characteristics of quality and the factors that influence it.

2. Two interrelated quality characteristics.

3. Two interrelated factors that affect quality characteristics.

\section{METHOD}

Research methods

In order to solve the problems that occur, the method that will be used is the Statistical Quality Control method.

\section{Data collection}

Data collection by direct observation and interviews. Direct observation is a way of collecting data using sight without any aids for this purpose. Primary and secondary data. The company's primary data include:

a. Data on the number of Base Single Part production in 2019.

b. Data on the number of Base Single parts with defects in 2019.

c. Data on the factors causing the damage. 


\section{Data Processing}

a. Control Chart $\mathrm{p}$

1. Calculating the average damage proportion

$\mathrm{p} 1=\frac{\mathrm{x} 1}{\mathrm{n} 1}$

Information :

$\mathrm{p} 1=$ the proportion of damage for

the first sample number

$\mathrm{x} 1=$ Number of defective items for

the first sample number

$\mathrm{n} 1=$ The number of items checked

for the first sample number

2. Calculating the Average Error Percentage

$$
\overline{\mathrm{p}}=\frac{\Sigma \mathrm{ri}}{\Sigma \mathrm{ni}}
$$

Information :

$\overline{\mathrm{p}}=$ Average damage proportion

$\Sigma \mathrm{ri}=$ Number of rejected units

$\Sigma \mathrm{ni}=$ Number of checked units in the subgroup

3. Each proportion of damage to each sample is depicted on the control chart of the proportion of damage that has the following limits:

$\overline{\mathrm{p}}=$ Sentral $=\frac{\text { jumlah proposi rusak }}{\text { jumlah sampel yang diperiksa }}$
$\mathrm{BKA}_{\mathrm{p}}=\overline{\mathrm{p}}+3 \sqrt{\frac{\overline{\mathrm{p}} \cdot \overline{\mathrm{q}}}{\mathrm{n}}}$

$\mathrm{BKB}_{\mathrm{p}}=\overline{\mathrm{p}}-3 \sqrt{\frac{\overline{\mathrm{p}} \cdot \overline{\mathrm{q}}}{\mathrm{n}}}$

Di mana :

BKA $=$ Upper Control Limit

$\mathrm{BKB}=$ Lower Control Limit

$\overline{\mathrm{p}}=$ How many rejected from the checked amount

$\mathrm{n}=$ Number of items in each sample

$$
\overline{\mathrm{q}}=1-\overline{\mathrm{p}}
$$

b. Diagram Sebab Akibat (Fishbone)

Cause and effect diagram (Fishbone) to describe all the causal factors associated with the problem under study.

\section{RESULTS AND DISCUSSION}

The data obtained by the author is Base Single Part damage data in 2019. Before calculating the damage percentage control chart, data on the number of defective items and data on the amount of production using samples are needed.

Tabel 3 : Result of Control Diagram p

\begin{tabular}{|c|c|c|c|c|c|c|c|c|}
\hline No & Period & $\begin{array}{c}\text { Production } \\
\text { Quantity } \\
(\text { Pcs })\end{array}$ & $\begin{array}{c}\text { Total } \\
\text { Defects } \\
(\text { Pcs })\end{array}$ & $\begin{array}{c}\text { Disability } \\
\text { Percentage }\end{array}$ & $\bar{p}$ & BKA & BKB & Information \\
\hline 1 & January & 845 & 119 & $14,08 \%$ & $12,70 \%$ & $16,13 \%$ & $9,26 \%$ & In Control \\
\hline 2 & Februart & 368 & 52 & $14,13 \%$ & $12,70 \%$ & $17,90 \%$ & $7,49 \%$ & In Control \\
\hline 3 & March & 739 & 105 & $14,21 \%$ & $12,70 \%$ & $16,37 \%$ & $9,02 \%$ & In Control \\
\hline 4 & April & 964 & 134 & $13,90 \%$ & $12,70 \%$ & $15,91 \%$ & $9,48 \%$ & In Control \\
\hline 5 & May & 1267 & 173 & $13,65 \%$ & $12,70 \%$ & $15,50 \%$ & $9,89 \%$ & In Control \\
\hline 6 & June & 2415 & 294 & $12,17 \%$ & $12,70 \%$ & $14,73 \%$ & $10,66 \%$ & In Control \\
\hline 7 & July & 3329 & 396 & $11,90 \%$ & $12,70 \%$ & $14,43 \%$ & $10,96 \%$ & In Control \\
\hline
\end{tabular}


ISBN 978-623-92199-2-5

\begin{tabular}{|c|c|c|c|c|c|c|c|c|}
\hline No & Period & $\begin{array}{l}\text { Production } \\
\text { Quantity } \\
\text { (Pes) }\end{array}$ & $\begin{array}{c}\text { Total } \\
\text { Defects } \\
\text { (Pcs) }\end{array}$ & $\begin{array}{l}\text { Disability } \\
\text { Percentage }\end{array}$ & $\bar{p}$ & BKA & BKB & Information \\
\hline 8 & August & 2178 & 329 & $15,11 \%$ & $12,70 \%$ & $14,84 \%$ & $10,56 \%$ & $\begin{array}{l}\text { Out of } \\
\text { Control }\end{array}$ \\
\hline 9 & September & 2819 & 291 & $10,32 \%$ & $12,70 \%$ & $14,58 \%$ & $10,81 \%$ & $\begin{array}{c}\text { Out of } \\
\text { Control }\end{array}$ \\
\hline 10 & October & 3642 & 568 & $15,60 \%$ & $12,70 \%$ & $14,35 \%$ & $11,04 \%$ & $\begin{array}{c}\text { Out of } \\
\text { Control }\end{array}$ \\
\hline 11 & November & 3449 & 394 & $11,42 \%$ & $12,70 \%$ & $14,40 \%$ & $10,99 \%$ & In Control \\
\hline 12 & December & 3207 & 347 & $10,82 \%$ & $12,70 \%$ & $14,46 \%$ & $10,93 \%$ & In Control \\
\hline & Total & 25222 & 3202 & & & & & \\
\hline
\end{tabular}

Based on the table above, a p control chart can be made which can be seen in Figure 1

There are nine controlled points, namely in January, February, March, April, May, June, July, November and December. The remaining three points are outside the control limits, this shows that there are special causes that occur at three points outside the control limits, namely in August, September and Oktober, with the percentage of defects in August $15.11 \%$, in September $10.32 \%$, and in October $15.60 \%$, Therefore it is necessary to make improvements by eliminating points that are outside the control limits, can be seen in Tabel 3

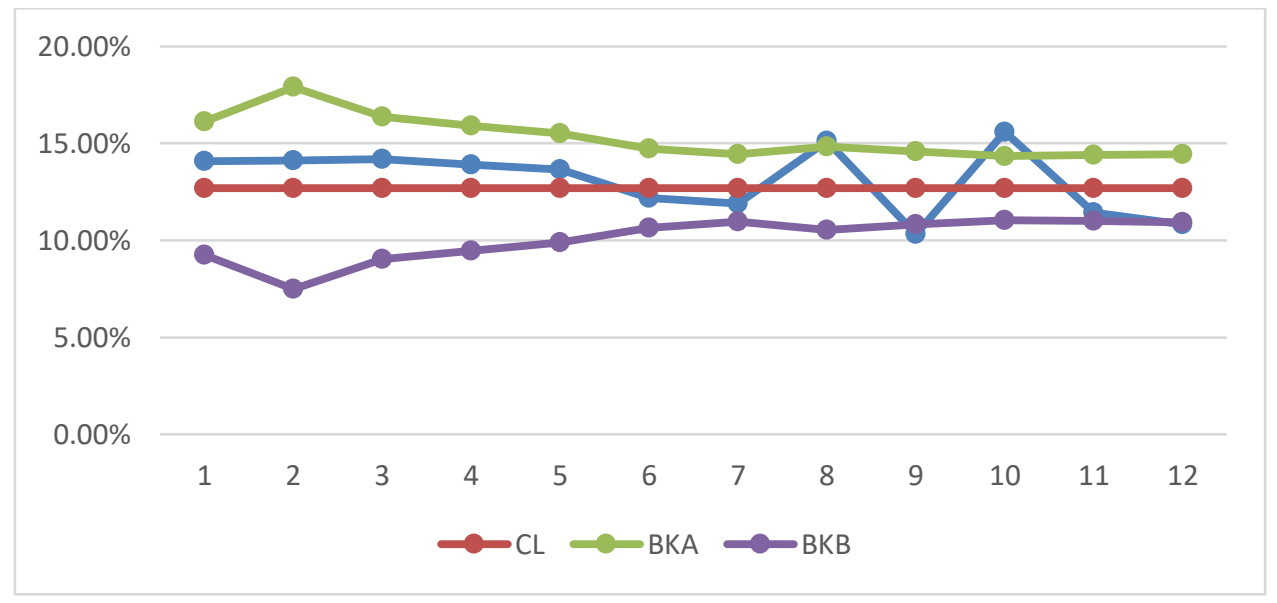

Figure 1 : Single Part Base Damage Percentage Control Chart 2019

By eliminating these points, it will change the control limit. In below is
Figure 2 the result of calculating the percentage of damage: 


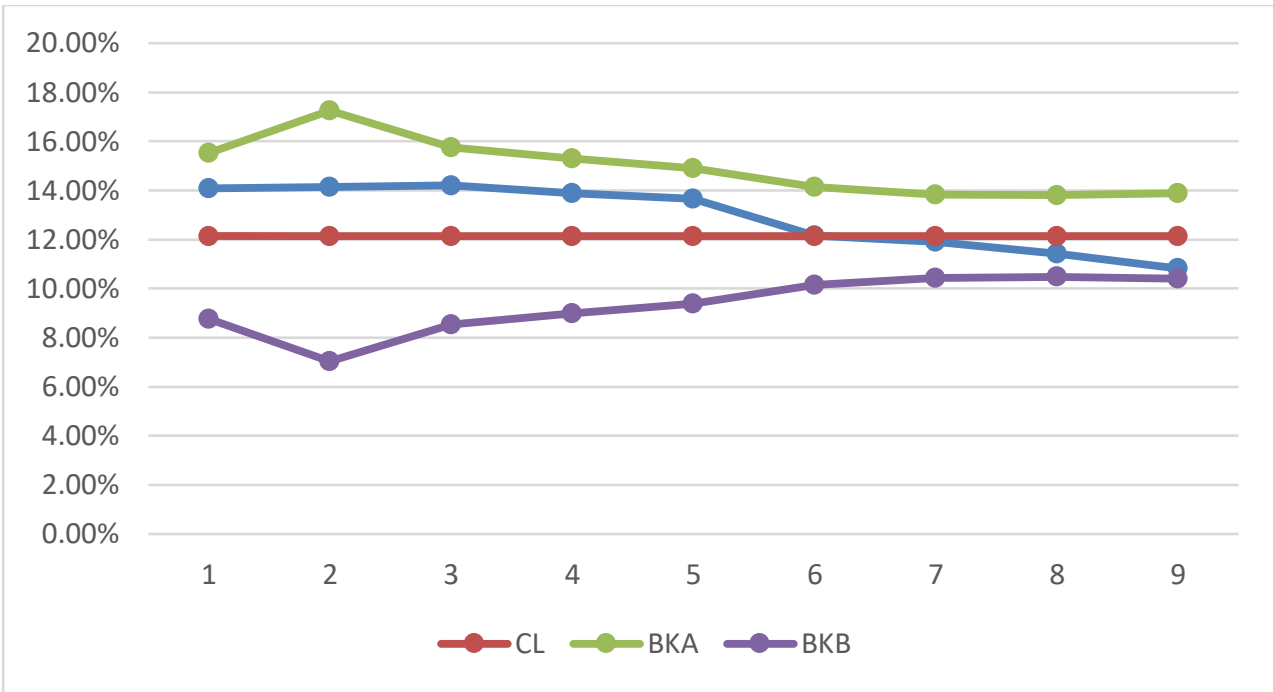

Figure 2 : Single Part Base Defect Percentage Repair Control Chart in 2019

Based on the results of the analysis, the

Fishbone diagram to see the factors that

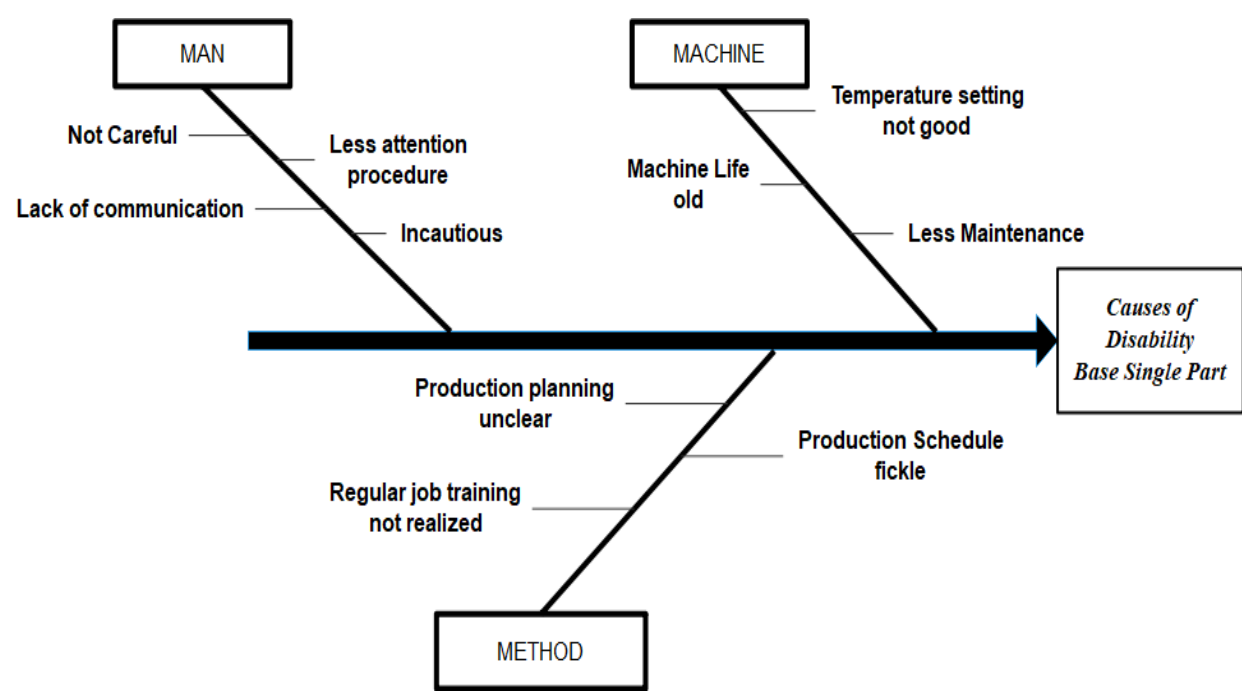

affect cause Base Single Part defects, namely:

Figure 3 : Base Single Part Disability August, September, October 2019

Based on the results of the Fishbone diagram analysis above, it can be seen that the factors that cause Base Single Part defects are human factors, method factors, and machine factors. The causes of the damage when viewed from the human factor are lack of accuracy, lack of communication, lack of attention to procedures and the existence of overtime politics that intentionally made 


\section{CONCLUSION}

The percentage of the Base Single Part component defect rate in 2019 is that there are 3 percentage points that are out of control where the 3 points are in August the percentage is $15.11 \%$, September $10.32 \%$, and October $15.60 \%$, but after recalculation is carried out by eliminating 3 points that are outside the control limit, the percentage of defects for these 9 points is within the control limit and defects can be tolerated. Next to find out the factors that cause 3 points outside the control limit, namely by using causal diagram analysis / Fishbone diagram, from the analysis the author concludes that the factors causing the defect of the Base Single Part component are composed of 3 factors, human factors, method factors and machine factors. The human factor is workers who are less productive. The next factor is the method of changing production schedules and the lack of training provided to workers. Furthermore, the last cause is from the engine factor less maintenance and machine life The old ones also cause vacuum suction that is not optimal and causes the mold to move and result in production Base Single Part component is defective.

\section{DAFTAR PUSTAKA}

[1] Nasution, N, M,"Manajemen Mutu Terpadu (Total Quality Management)." Ghalia Indonesia, Bogor, 2005
[2] Assauri, Sofjan, "Manajemen Operasi Dan Produksi." LP FE UI, Jakarta 2004

[3] Hairiyah, Amalia, dan Luliyanti, "Analisis Statistical Quality Control (SQC) pada Produksi Roti di Aremania Bakery." Jurnal Teknologi dan Manajemen Agroindustri, Vol 8, No 1, 2019.

[4] Heizer, Jay, dan Barry Render, "Managemen Operasi." Edisi 7, Salemba Empat, Jakarta, 2006

[5] Gunawan, Imam, "Pengantar Statistika Inferensial." PT.Raja Grafindo Persada, Jakarta, 2017

[6] Sidartawan, Robertus, "Analisa Pengendalian Proses Produksi Snack Menggunakan Metode Statistical Process Control (SPC)." Jurnal ROTOR, Vol 7, No 2, 2014.

[7] Syukron, A dan Kholil, M, "Six Sigma Quality For Business Improvement," Graha Ilmu, Yogyakarta, 2013

[8] Gaspersz, Vincent, "Statistiqal Process Control Penerapan Teknikteknik Statistikal Dalam Manajemen Bisnis Total." PT Gramedia Pustaka. Jakarta, 1998.

[9] Octavia, Prajogo, Prabudy, "Studi Tentang Peta Kendali P Yang Distandarisasi Untuk Proses Pendek Kualitas." Jurnal Teknik Industri, Vol 2, No 1, 2000

[10] Amitava, Mitra, "Fundamental of Quality Control and Improvement." Johm Wiley \& Sons, Inc., Hoboken, New Jersey, , Canada, 2016. [Tersedia pada: Labrary Genesis] 